\title{
INFLUENCE OF THE CARBIDE-PARTICLE SPHEROIDISATION PROCESS ON THE MICROSTRUCTURE AFTER THE QUENCHING AND ANNEALING OF 100CrMnSi6-4 BEARING STEEL
}

\author{
VPLIV PROCESA SFEROIDIZACIJE KARBIDNIH DELCEV NA \\ MIKROSTRUKTURO JEKLA 100CrMnSi6-4 ZA LEŽAJE PO \\ KALJENJU IN POPUŠČANJU
}

\author{
Jaromir Dlouhy, Daniela Hauserova, Zbysek Novy \\ COMTES FHT, Prumyslova 995, 33441 Dobrany, Czech Republic \\ jdlouhy@,comtesfht.cz
}

Prejem rokopisa - received: 2014-12-12; sprejem za objavo - accepted for publication: 2015-01-21

doi: $10.17222 /$ mit. 2014.303

\begin{abstract}
Bearings are used mostly in the quenched and tempered state, e.g., steel 100CrMnSi6-4 with a microstructure of low-tempered martensite and carbide particles undissolved during the quenching austenitization. The size and density of the particles depend on the spheroidisation annealing which is the standard operation at the beginning of the bearing manufacturing. The particles decrease the grain growth of the austenite and determine the grain size after the quenching. The process of accelerated carbide spheroidisation and refinement (ASR) was developed and is used as a replacement of the conventional spheroidisation soft annealing. The ASR process produces the structure of a ferritic matrix and fine globular carbides. The carbide size is several times smaller in comparison with the conventional soft annealing. This microstructure is better for quenching and tempering and ensures a better bearing performance. The article compares the structures and properties of the quenched and tempered 100CrMnSi6-4 steel pre-treated with the conventional soft annealing and ASR. The smaller ASR particle size allows the use of lower quenching temperatures, ensuring the desired final hardness. Samples in the hardened state were compared, considering the prior-austenite grain size, the carbide-particle size and distribution as well as the hardness.
\end{abstract}

Keywords: accelerated spheroidisation, carbide-particle morphology, hardening, bearing steel

Ležaji se običajno uporabljajo v kaljenem in popuščenem stanju, na primer jeklo 100CrMnSi6-4 z mikrostrukturo nizko popuščenega martenzita in s karbidnimi delci, ki se ne raztopijo pri avstenitizaciji pred kaljenjem. Velikost in pogostost delcev je odvisna od sferoidizacijskega žarjenja, ki je standardna operacija na začetku izdelovanja ležaja. Delci zavirajo rast avstenitnih zrn in določajo velikost zrn po kaljenju. Razvit je bil postopek pospešene sferoidizacije in udrobnjenja karbidov (ASR), ki je bil uporabljen namesto običajnega sferoidizacijskega mehkega žarjenja. Pri ASR procesu nastane feritna osnovna mikrostruktura in drobni globularni karbidi. Velikost karbidov je nekajkrat manjša v primerjavi z običajnim mehkim žarjenjem. Taka mikrostruktura je boljša za kaljenje in popuščanje in zagotavlja boljše lastnosti ležaja. V članku so primerjane mikrostrukture in lastnosti kaljenega in popuščanega jekla 100CrMnSi6-4 predhodno mehko žarjenega in ASR. Manjša velikost delcev pri ASR omogoča uporabo nižje temperature kaljenja za doseganje željene trdote. Vzorci v utrjenem stanju so bili primerjani z upoštevanjem velikosti prvotnih avstenitnih zrn, velikosti in razporeditve karbidnih delcev, kot tudi trdote.

Ključne besede: pospešena sferoidizacija, morfologija karbidnih zrn, kaljivost, jeklo za ležaje

\section{INTRODUCTION}

Bearing steels are well studied in terms of the effect of the technological parameter on the final microstructural properties. ${ }^{1}$ The final properties of a hardened product depend on the parameters of hardening, e.g., the austenitization temperature and or the tempering temperature. Their influence on the hardness and prioraustenite grain size was studied properly. Much less attention was paid to the influence of the initial material microstructure on the final material properties. The soft annealed microstructure, used as the standard material state for hardening, consists of globular carbide particles with a size mostly from $0.5 \mu \mathrm{m}$ to $1 \mu \mathrm{m}$ dispersed in the ferritic matrix. Two initial states were used for the hardening - the conventional soft-annealed state and the state after accelerated carbide spheroidisation and refinement (ASR). ${ }^{2}$ The ASR state exhibits the same microstructural morphology, but the globular carbides are about 3-times smaller than after the soft annealing and are also more densely spread in the ferritic matrix. ${ }^{3,4}$ Such a significantly finer structure provides for a faster

Table 1: Chemical composition of the 100CrMnSi6-4 bearing steel in mass fractions ( $w / \%)$

Tabela 1: Kemijska sestava 100CrMnSi6-4 jekla za ležaje v masnih deležih (w/\%)

\begin{tabular}{|c|c|c|c|c|c|c|c|c|c|c|}
\hline $\mathrm{C}$ & $\mathrm{Si}$ & $\mathrm{Mn}$ & $\mathrm{P}$ & $\mathrm{S}$ & $\mathrm{Cr}$ & $\mathrm{Mo}$ & $\mathrm{Ni}$ & $\mathrm{Al}$ & $\mathrm{Cu}$ & $\mathrm{Fe}$ \\
\hline 0.98 & 0.54 & 1.14 & 0.011 & 0.011 & 1.50 & 0.006 & 0.02 & 0.018 & 0.017 & bal. \\
\hline
\end{tabular}


carbide-particle dissolution during the austenitization at the quenching temperature ${ }^{3}$ and a stronger pinning of the grain boundaries, thus leading to a smaller austenite grain size due to the pinning effect and a martensitic structure after the quenching. These microstructural features can lead to a higher hardness and toughness with the same hardening parameters. Another possibility is to reduce the quenching temperature or austenitization time, but still with good final mechanical properties. ${ }^{5,6}$

\section{EXPERIMENTAL WORK}

\subsection{Material}

The experimental material was the 100CrMnSi6-4 bearing steel grade with the chemical composition shown in Table 1. The material was supplied as hot-rolled $21 \mathrm{~mm}$-diameter bars, with a microstructure of pearlite and a small amount of secondary cementite along the austenite boundaries and a hardness of 383 HV10. The samples were cut in the form of $30 \mathrm{~mm}$ long cylinders.

\subsection{Spheroidisation annealing}

The initial pearlitic microstructure was spheroidised and samples with fine and coarse globular pearlite were prepared. The coarse structure was obtained with the conventional soft annealing in an atmospheric furnace at a temperature of $805{ }^{\circ} \mathrm{C}$ for $11 \mathrm{~h}$ and air cooling. Fully spheroidised pearlite consisted of cementite globules with diameters of $0.3-1 \mu \mathrm{m}$ in the ferritic matrix. The fine structure was obtained with the ASR heat treatment consisting of three temperature cycles. Each cycle consisted of the induction heating to $780{ }^{\circ} \mathrm{C}$, a 15 -second dwell period at this temperature and cooling in air to a temperature of $650{ }^{\circ} \mathrm{C}$. The overall annealing duration was $5 \mathrm{~min}$. The structure after the ASR process consisted of globular carbides with a size of $0.1-0.3 \mu \mathrm{m}$ dispersed in the ferritic matrix.

\subsection{Quenching and tempering}

The heating to the quenching temperature was performed in an electric atmospheric furnace. The samples were held at the austenitization temperature for $30 \mathrm{~min}$. Austenitization temperatures of $(800,820,840$ and 860$){ }^{\circ} \mathrm{C}$ were used. The quenching was performed in an oil bath, immediately followed by tempering. All the samples were tempered for $4 \mathrm{~h}$ at a temperature of $240{ }^{\circ} \mathrm{C}$.

\subsection{Sample analyses}

All the samples were cut longitudinally and metallographic specimens were prepared by mechanical grinding, polishing and Nital etching. The microstructure was examined with SEM JEOL 7400F. The prior-austenite grain size $(P A G S)$ was assessed on the samples etched in a picric-acid-saturated aqueous solution at a temperature of $80^{\circ} \mathrm{C}$ and the average grain diameter was determined with a linear intercept procedure. The hardness was measured with the Vickers method at a load of HV10.

\section{RESULTS AND DISCUSSION}

\subsection{Microstructure analyses}

The microstructures after the soft annealing and ASR treatment are shown in Figures $\mathbf{1}$ and 2. Much finer carbide globules were formed during the ASR treatment. Figures 3 and $\mathbf{4}$ show quenched-sample microstructures (quenched from $800{ }^{\circ} \mathrm{C}$ ). There is a clear difference in the carbide density between the samples. This difference is pronounced with higher austenitizing temperatures.

The ASR-treated samples retained a much denser carbide distribution even after the quenching from $860{ }^{\circ} \mathrm{C}$ (Figures 5 and 6). A higher dispersion strengthening could cause a hardness increase in comparison with the conventionally soft-annealed samples. Apparently, a denser carbide distribution causes a pronounced pinning effect on the prior-austenite grain boundaries. There were coarse carbides retained in the soft-annealed samples after the quenching from higher temperatures

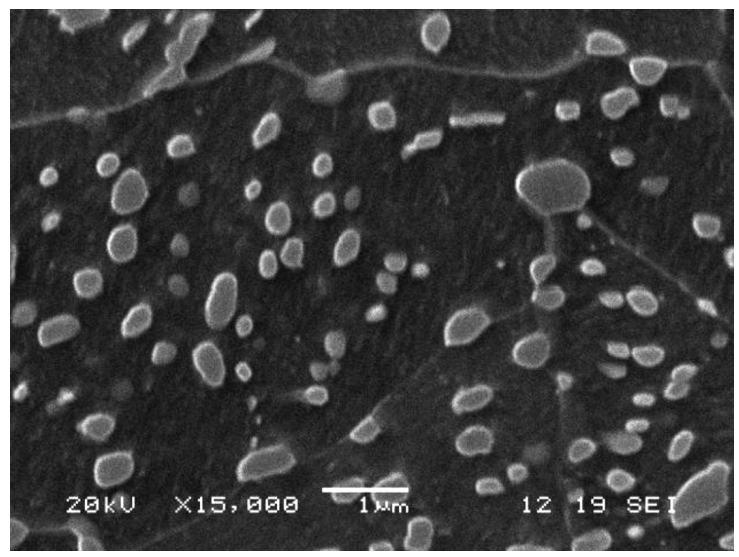

Figure 1: Conventionally soft-annealed sample

Slika 1: Običajno mehko žarjen vzorec

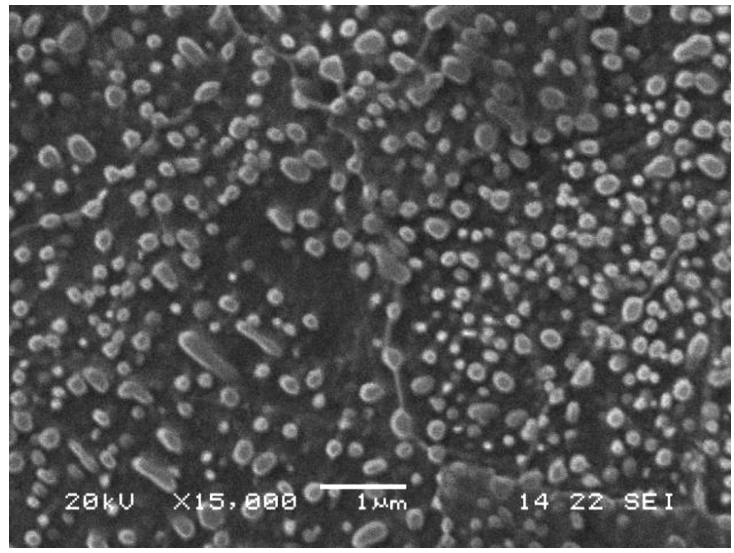

Figure 2: ASR-treated sample with finer carbides Slika 2: ASR-obdelan vzorec z drobnimi karbidi 


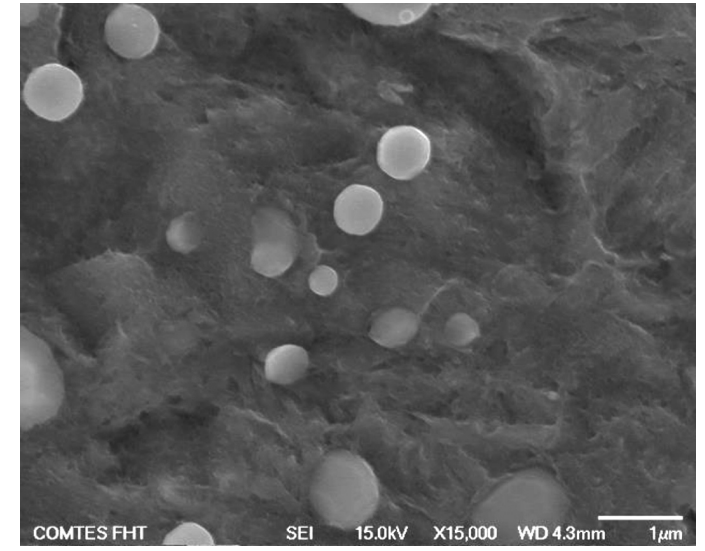

Figure 3: Soft-annealed sample quenched from $800{ }^{\circ} \mathrm{C}$ Slika 3: Mehko žarjen vzorec po kaljenju iz $800{ }^{\circ} \mathrm{C}$

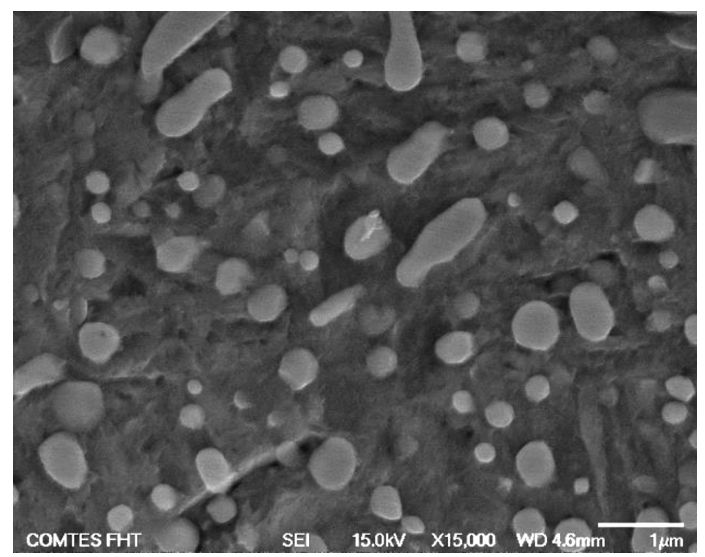

Figure 4: ASR-treated sample quenched from $800{ }^{\circ} \mathrm{C}$ Slika 4: ASR-obdelan vzorec po kaljenju iz $800{ }^{\circ} \mathrm{C}$

(840 and $\left.860{ }^{\circ} \mathrm{C}\right)$. Smaller carbides with a size of up to $0.5 \mu \mathrm{m}$ were almost completely dissolved.

\subsection{Hardness and PAGS}

Different austenitization temperatures resulted in different hardness values found after the quenching and

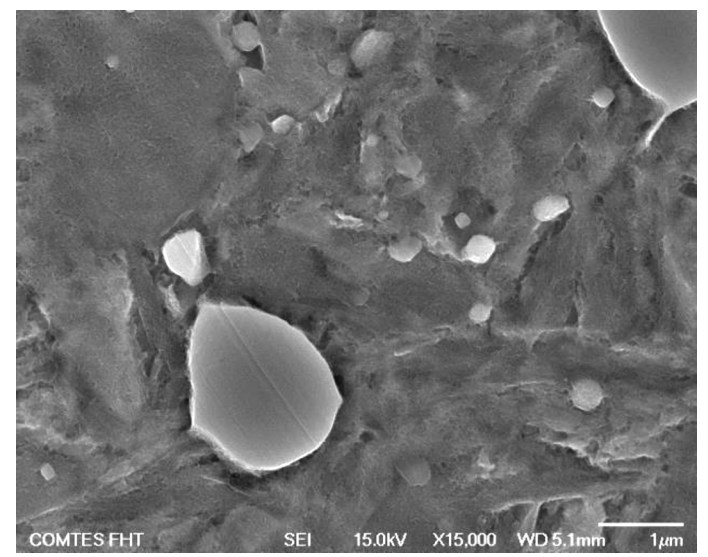

Figure 5: Soft-annealed sample quenched from $800{ }^{\circ} \mathrm{C}$

Slika 5: Mehko žarjen vzorec po kaljenju iz $800{ }^{\circ} \mathrm{C}$

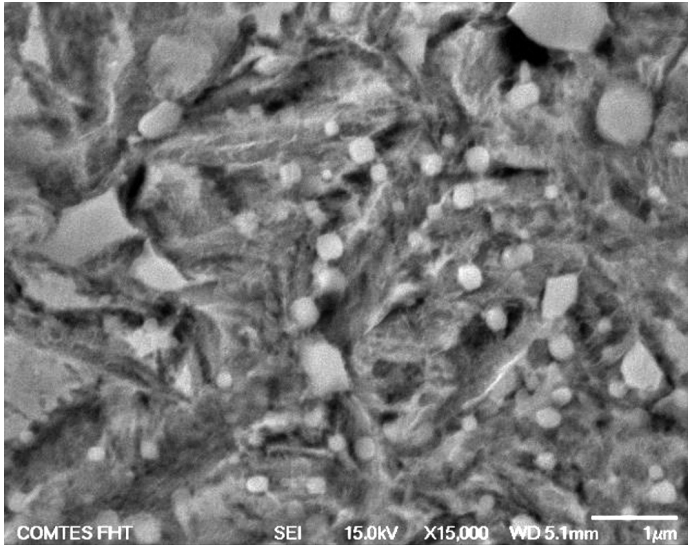

Figure 6: ASR-treated sample quenched from $800{ }^{\circ} \mathrm{C}$

Slika 6: ASR-obdelan vzorec po kaljenju iz $800{ }^{\circ} \mathrm{C}$

tempering and also in different $P A G S$ values. There were significant differences between the samples with coarse and fine structures as shown in Figure 7.

There is a clear trend in the hardness value in the case of the conventionally soft-annealed samples with coarse carbides in the microstructure. A higher austenitization temperature caused a hardness increase due to the dissolution of a larger amount of carbon. On the other hand, there is no clear trend in the case of the hardness of the quenched ASR samples. The hardness after the tempering increased with the quenching temperature and was significantly higher with all the quenching temperatures in comparison with the conventionally soft-annealed samples.
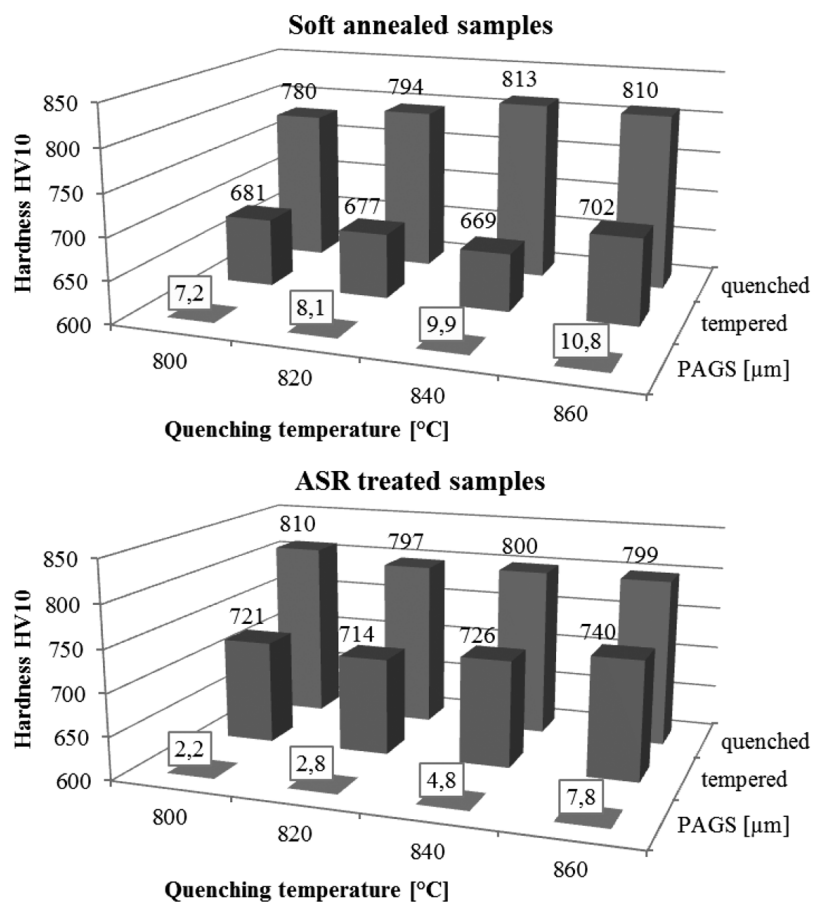

Figure 7: Hardness and PAGS of samples after quenching and tempering

Slika 7: Trdota in $P A G S$ vzorcev po kaljenju in po popuščanju 


\section{J. DLOUHY et al.: INFLUENCE OF THE CARBIDE-PARTICLE SPHEROIDISATION PROCESS ON THE MICROSTRUCTURE ...}

The PAGS is much smaller in the case of the ASR-treated samples. Its values grew with the increasing quenching temperature for both sample types - the ASR-treated and conventionally soft-annealed samples. The finer-structured ASR-treated samples exhibited a more pronounced $P A G S$ increase. Finer carbides dissolved at higher quenching temperatures and thus their pinning effect on the austenite grain boundaries was diminished. The difference between the PAGS values of the ASR and soft-annealed samples decreased with the rising quenching temperatures.

\section{CONCLUSION}

The microstructures and hardness values of hardened samples with different initial microstructures were compared. The influence of the carbide-particle density is clearly visible in terms of the prior-austenite grain size and hardness. The samples with fine carbides after the ASR process had higher hardness values after the quenching and tempering for the whole range of examined quenching temperatures from 800 to $860{ }^{\circ} \mathrm{C}$. The hardness increase was about 40 HV10 in comparison with the conventionally soft-annealed samples with coarser carbide particles and was probably caused by the dispersion strengthening and a possible higher dissolution of the fine carbides during the austenitization.

\section{Acknowledgment}

This paper was created by project Development of West-Bohemian Centre of Materials and Metallurgy No.: LO1412, financed by the MEYS of the Czech Republic.

\section{REFERENCES}

${ }^{1}$ H. K. D. H. Bhadeshia, Steels for bearings, Progress in Materials Science, 57 (2012), 268-435, doi:10.1016/j.pmatsci.2011.06.002

${ }^{2}$ D. Hauserova, J. Dlouhy, Z. Novy, Microstructure Development of Bearing Steel during Accelerated Carbide Spheroidisation, Materials Science Forum, 782 (2014), 123-128, doi:10.4028/ www.scientific.net/MSF.782.123

${ }^{3}$ J. H. Kang, P. E. J. Rivera-Díaz-del-Castillo, Carbide dissolution in bearing steels, Computational Materials Science, 67 (2012), 364-372, doi:10.1016/j.commatsci.2012.09.022

${ }^{4}$ D. Hauserova, J. Dlouhy, Z. Novy, J. Zrnik, Accelerated carbide spheroidization and refinement (ASR) of the C45 steel during induction heating, Mater. Tehnol., 47 (2013) 6, 701-705

${ }^{5}$ H. Jirkova, D. Hauserova, L. Kucerova, B. Masek, Energy- and time-saving low-temperature thermomechanical treatment of lowcarbon plain steel, Mater. Tehnol., 47 (2013) 3, 335-339

${ }^{6}$ A. I. Katsamas, A computational study of austenite formation kinetics in rapidly heated steels, Surface \& Coatings Technology, 201 (2007), 6414-6422, doi:10.1016/j.surfcoat.2006.12.014 